\title{
Diphasic Dialysis Extraction Technique for Clenbuterol Determination in Bovine Retina by Gas Chromatography - Mass Spectrometry
}

\author{
F. Ramos* / A. Matos / A. Oliveira / M. I. Noronha da Silveira \\ Laboratório de Bromatologia, Nutriçao e Hidrologia, Faculdade de Farmácia, Universidade de Coimbra, 3049 Coimbra \\ codex, Portugal
}

\section{Key Words \\ Gas chromatography-mass spectrometry \\ Diphasic dialysis \\ Clenbuterol in bovine retinas \\ Boronic derivatisation}

\begin{abstract}
Summary
A method is described for the extraction of clenbuterol from bovine retina samples by diphasic dialysis using gas chromatography - mass spectrometry (GC-MS) as the procedure of determination. Following chemical digestion of retinal tissue in alkaline medium at $80^{\circ} \mathrm{C}$, clenbuterol is extracted by diphasic dialysis using diethyl ether as solvent at $37^{\circ} \mathrm{C}$, for $4 \mathrm{~h}$ at $150 \mathrm{rpm}$. Diethyl ether is evaporated to dryness and clenbuterol determined by GC-MS after butylboronic acid (BBA) derivatization. A detection limit of $2.5 \mathrm{ng} \mathrm{g}^{-1}$, repeatability of $9.0 \%$ and reproducibility of $22.9 \%$, with recoveries always $>86 \%(n=5)$, are achieved as validation criteria.
\end{abstract}

\section{Introduction}

$\beta_{2}$-adrenergic agonists have been used for quite some time, both in human and veterinary medicine, mainly as bronchodilators and tocolithics. However, they have also been used for the past decade, although illegally, as promoters of animal growth for such species as chickens, pigs, sheep and catlle [1-4]. Clenbuterol (4-amino3,5-dichloro- $\alpha$-[(tert-butylamino) methyl] benzyl alcohol hydrochloride) is undoubtedly the most frequently used $\beta_{2}$-adrenergic agonist for the latter purpose [5]; therefore, it is not surprising to find such a large number and variety of analytical methods for its determination.

Various recent studies [6-9] have shown the potential for pigmented tissues in control programmes for unauthorised substances in animal husbandry, particularly clenbuterol, due to the selective fixation which occurs between melanin and these substances and remains stable. The retina is, therefore, a widely used matrix in most clenbuterol determination techniques, such as immunological tests, radioimmunoassay [6] or enzyme immunoassay [7-11], and in chromatographic techniques such as: HPLC with UV [12] or electrochemical [13] detection and GC - MS [14], after various extraction or purification procedures, such as liquid-liquid extraction [13-14] and solid-phase extraction [12].

Diphasic dialysis enables selective and efficient extraction from aqueous media of compounds of low molecular mass, using organic solvents and without need for complementary purifying procedures; it has already been utilised to extract clenbuterol from urine [15] and liver [16-17].

This paper describes a method for the rapid determination of clenbuterol residues in bovine retina, using diphasic dialysis as the extracting procedure and GC-MS as the determination technique, following derivatization with butylboronic acid.

\section{Experimental}

\section{Reagents and Materials}

Clenbuterol was from Interchim (Montluçon, France) and tri-deuterated (D3) clenbuterol (internal standard) as kindly supplied by Dr Jan Rud Andersen (Danish Meat Institute, Roskilde, Denmark). Butylboronic acid (BBA) and ethyl acetate stored over molecular sieve were from Fluka (Buchs, Switzerland). All other reagents were from Merck (J.M. Vaz Pereira, Lisbon, Portugal). Nitrogen N45 and helium N55 were suplied by Sofager (Coimbra, Portugal). Visking dialysis tubing 20/32 with a molecular exclusion size of $12000-14000$ Da (Medicell International, London, UK) was from Reagente 5 (Oporto, Portugal).

Retina digestion was performed in a Memmert oven (Schwabach, Germany) regulated at $80^{\circ} \mathrm{C}$ and for diphasic dialysis an incubator shaker model G25 New Brunswick Scientific (Edison, NJ, USA) was used. 
Table I. - Validation data $(\mathrm{n}=5)$

\begin{tabular}{|lc|}
\hline Criteria & Data \\
\hline Detection limit & $2.5 \mathrm{ng} \mathrm{g}^{-1}$ \\
Recovery & \\
$\quad\left(60 \mathrm{ng} \mathrm{g}^{-1}\right)$ & $96.1 \%$ \\
$\quad\left(80 \mathrm{ng} \mathrm{g}^{-1}\right)$ & $86.1 \%$ \\
$\quad\left(100 \mathrm{ng} \mathrm{g}^{-}\right) 88.1 \%$ & $9.0 \%$ \\
Repeatability (C. V.) & $22.9 \%$ \\
Reproducibility (C. V.) & \\
\hline
\end{tabular}
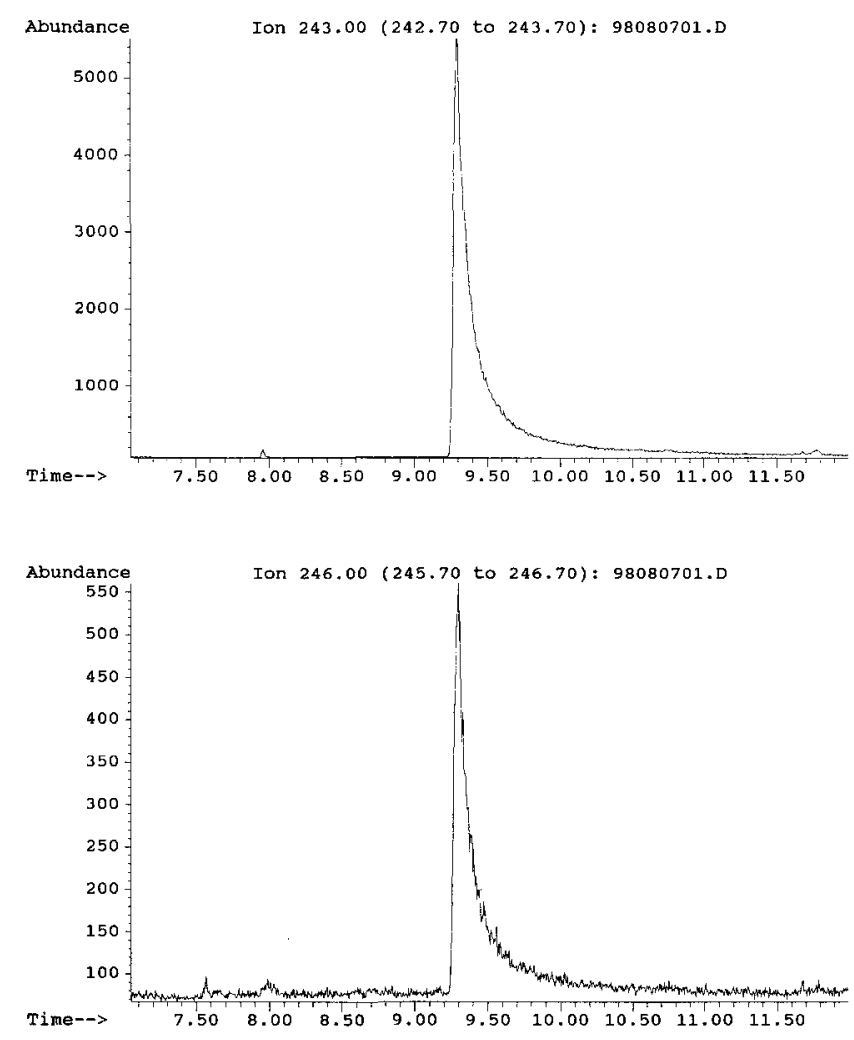

Figure 1

Chromatogram of a real sample

Clenbuterol determination was achieved on a Hewlett Packard (HP) apparatus, comprising an HP5890 series II gas chromatograph, HP6890 autosampler, HP5972 MSD detector, HP Vectra VL2 4/50 computer, HP Deskjet 520 printer, and a $25 \mathrm{~m} \times 0,32 \mathrm{~mm}$ Permabond OV1-DF column, $0.25 \mu \mathrm{m}$ film thickness (Soquímica, Lisbon, Portugal).

A Mettler AE200 balance (Zurich, Switzerland), pH meter CD 7400-WPA (Cambridge, UK), nitrogen evaporation system and a vortex type mixer (Reagente 5 , Oporto, Portugal) were also used.

\section{Sample Preparation}

The retina was separated from the remainder of the eyeball, cut with a scalpel blade and weighed $( \pm 1.0 \mathrm{~g})$ into a screw-capped centrifuge tube. $3 \mathrm{~mL} \mathrm{M} \mathrm{NaOH}$ and $50 \mu$ clenbuterol D3 were added at a concentration of $1 \mu \mathrm{g} \mathrm{mL}^{-1}$ in methanol. Digestion was carried out for $2 \mathrm{~h}$ and frequently stirred. The digest was then transferred with $20 \mathrm{~mL}$ acetate buffer [sodium acetate $0.2 \mathrm{M}$ : acetic acid $(95: 5) \mathrm{pH} \approx 5.8]$ to an Erlenmeyer flask, where $20 \mathrm{~cm}$ of previously-hydrated dialysis membrane had been placed with $25 \mathrm{~mL}$ diethyl ether. Diphasic dialysis was performed for $4 \mathrm{~h}$ at $37^{\circ} \mathrm{C}$ and at $150 \mathrm{rpm}$ [16-17]. The contents of the membrane were then transferred to a separation funnel, and, after phase separation, ether extract was placed in a centrifuge tube and evaporated to dryness under nitrogen at $55^{\circ} \mathrm{C}$. The dry residue was dissolved in $2 \times 200 \mu \mathrm{L}$ methanol in a derivatisation vial. The methanol was also evaporated at $55^{\circ} \mathrm{C}$ under nitrogen and the dry residue dissolved in $50 \mu \mathrm{L}$ of a BBA ethyl acetate solution at a concentration of $5 \mathrm{mg} \mathrm{mL}^{-1}$. Then, the sample was derivatized $\left(1 \mathrm{~h}\right.$ at $\left.55^{\circ} \mathrm{C}\right)$ [18]

\section{Chromatography}

$2 \mu \mathrm{L}$ of the derivative were injected into the GC-MS system in splitless mode ( 1 min delay) using helium carrier gas at $1 \mathrm{~mL} / \mathrm{min}^{-1}$. The initial oven temperature was $120^{\circ} \mathrm{C}$ for $6 \mathrm{sec}$ and the programm was $15^{\circ} \mathrm{C} \mathrm{min}^{-1}$ to $245^{\circ} \mathrm{C}$ and $30^{\circ} \mathrm{C} \mathrm{min}{ }^{-1}$ to $300^{\circ} \mathrm{C}(5 \mathrm{~min})$. Detector and injector temperatures were $280^{\circ} \mathrm{C}$ and $260^{\circ} \mathrm{C}$, respectively. Analyses were performed in the electron impact mode and data acquisition was by selection of the $342,327,245$ and $243 \mathrm{~m} / \mathrm{z}$ ions for clenbuterol-BBA and 246 and $345 \mathrm{~m} / \mathrm{z}$ ions for clenbuterolD3-BBA derivatives. Analytical data were from the area ratios of $\mathrm{m} /$ z 243 and $\mathrm{m} / \mathrm{z} 246$ ions, respectively for clenbuterol and clenbuterolD3.

\section{Results and Discussion}

Five different $0.2 \mathrm{M}$ buffers (acetate, phosphate, borate, carbonate and citrate) and four organic solvents (dichloromethane, n-hexane, ethyl acetate and diethyl ether) were tested in the development of this diphasic dialysis procedure. The choice of acetate buffer and diethyl ether was based on their superior chromatographic peak resolution and, consequently, greater sensitivity, compared with the other above mentioned solvents.

Table I shows the data for repeatability, reproducibility, recovery and detection limits found, being within the reference values published by various authors [19-23]. Linearity was evaluated for 1 month with five separate standard samples, between 0.4-2.0 ng clenbuterol, $r$ values being found between the limits of 0.985 and 0.999 .

Figure 1 shows the chromatogram of a sample containing $23.7 \mathrm{ng}$ of clenbuterol $\mathrm{g}^{-1}$ of retina, obtained by the proposed method.

The use of diphasic dialysis as an extraction procedure for clenbuterol in bovine retina thus proved to be efficient, due to the fact that, although the total analysis 
time is slightly longer than the previously-described methods [6-14], it enables a substantial reduction of the number of manipulations by the operator, thus reducing losses during analysis, freeing the operator, and decreasing final costs.

In conclusion, considering the complexity of the retina, the method shown has proved to be comparatively simple and with good detection limits.

\section{Acknowledgements}

The authors are grateful to PRODEP II program (action no. 5.2) and to the Portuguese Foundation for Science and Technology (F.C.T.) for financial support. The authors also want to thank Prof. Teresa Dinis for fruitful discussion and Microbiology Lab of Pharmacy Faculty of Coimbra University for technical facilities.

\section{References}

[1] G. Asato, P. Baker, R. Bass, T. Bentley, S. Chari, R. Dalrymple, D. France, P. Gingher, B. Lences, J.Pascavage, J. Pensack, C. Ricks, Agric. Biol. Chem. 48, 2883 (1984)

[2] H. J. Mersmann, Am. J. Physiol. 252, E85-E95 (1987)

[3] J.P. Hanrahn, "Beta-agonists and their effects on animal growth and carcass quality", Elsevier Appl. Sci., London, 1987, p. 137

[4] J. Inkster, F. Hovell, D. Kyle, D. Brown, G. Lobley, Brit. J. Nutr. 62, 285 (1989)

[5] F. Ramos, M. C. Castilho, M. I. N. Silveira, J. Assoc. Off. Anal. Chem. Int., 81544 (1998)

[6] L. Howells, M. Godfrey, M.J. Sauer, Analyst, 119, 2691 (1994)
[7] M.J. Sauer, S. P. L. Anderson, Analyst, 119, 2553 (1994)

[8] I. Dürsch, H. H. D. Meyer, S. Jäger, Anal. Chim. Acta, 275, 189 (1993)

[9] I. Dürsch, H. H. D. Meyer, H. Karg, J. Anim. Sci., 73, 2050 (1995)

[10] C. T. Elliot, S. R. H. Crooks, W.J. McCaughey, Vet. Rec. 137, $643(1995)$

[11] H. H. D. Meyer, L. M. Rinke, J. Anim. Sci., 69, 4538 (1991)

[12] P. G. Gigosos, T.F. Fernández, O. C. Mariz, C.A.F. Sampayo, C. F. Abuin, A. C. Sáez, J. Chromatogr. B, 677, 167 (1996)

[13] L. A. Lin, J. A. Tomlinson, R. D. Satzger, J. Chromatogr. A, 762, $275(1997)$

[14] W.J. Blanchflower, S. A. Hewitt, A. Cannavan, C. T. Elliot, D. G. Kennedy, Biol. Mass Spectrom., 22, 326 (1993)

[15] L. Dominguez, J. L. Blanco, M. A. Moreno, S. D. Diaz, J. Prieta, J.M. Cámara, J. Bayo, G. Suárez, J. Assoc. Off. Anal. Chem. Int., 75, 854 (1992)

[16] P. G. Gigosos, C. A. F. Sampayo, C.F. Abuín, B. V. Belda, E. Q. Fernández A. C. Sáez, Chromatographia, 43271 (1996)

[17] P. González, C. A. Fente, C. Franco, B. Vázquez, E. Quinto, A. Cepeda, J. Chromatogr. B, 693321 (1997)

[18] F. Ramos, C. Santos, A. Silva, M. I. N. Silveira, J. Chromatogr. B $716366(1998)$

[19] A. C. C. Campmany, E. E. Ferrer, C. F. Lastra, Farm. Clin., 7, $749(1990)$

[20] W. Horwitz, L. R. Kamps, K. W. Boyer, J. Assoc. Off. Anal Chem., 631344 (1980)

[21] W.D. Pocklington, Pure \& Appl. Chem., 62149 (1990)

[22] J. N. Miller, Analyst, 1163 (1991)

[23] R.J. Heitzman, "Residues in food-producing animals and their Products: Reference materials and methods", Commission of the European Communities, Luxembourg, 1992, p. 27

Received: Oct 22, 1998

Revised manuscript received: Jan 5, 1999 Accepted: Mar 3, 1999 